\title{
MODEL E-MARKETING BERBASIS FINTECH SYARIAH BERDASARKAN TINJAUAN LINGKUNGAN EKSTERNAL DAN INTERNAL UNTUK PENGEMBANGAN WISATA HALAL DI INDONESIA
}

\section{A FINTECH E-MARKETING MODEL BASED ON BOTH THE EKSTERNAL AND INTERNAL ENVIRONMENT REVIEW FOR HALAL TOURISM DEVELOPMENT IN INDONESIA}

\author{
Fauzi $^{1}$, A.Sanusi ${ }^{2}$, Basrowi ${ }^{3}$, P.Utami ${ }^{4}$ \\ ${ }^{1}$ STIMIK Pringsewu, Lampung, Indonesia. \\ ${ }^{2}$ Institut Informatika dan Bisnis Darmajaya (IIB Darmajaya) Lampung \\ ${ }^{3}$ Departemen Administrasi Publik Fakultas FISIP Universitas Muhammadiyah Jakarta \\ ${ }^{4}$ Mahasiswa Program Mahasiswa Pasca Sarjana Ekonomi Syariah UIN Raden Intan Lampung
}

\begin{abstract}
The purpose of this research is to establish a fintech e-marketing model that can develop halal tourist industries in Indonesia. This research uses a qualitative approach and the technique analysis with literature study. Based on literature review, it is likely that e marketing based on fintech sharia can support halal tourism, public welfare through UMKM, and increasing interest in halal tour in Indonesia. However, it seems that as far as Indonesia is concerned, it is still not ready to accelerate to the sector specially the use of e-marketing based on fintech.
\end{abstract}

Keyword: Strategy Management, Fintech, Organizational External and Internal Environments, Halal Tourism

\begin{abstract}
ABSTRAK
Tujuan penelitian ini adalah untuk menyusun model e-marketing berbasis fintech yang dapat mengembangkan industry pariwisata halal di Indonesia. Penelitian ini menggunakan pendekatan kualitatif dan dilakukan dengan studi literatur. Berdasarkan tinjauan literatur, kemungkinan besar E-Marketing berbasis fintech syariah dapat mendukung perkembangan wisata halal, kesejahteraan masyarakat melalui UMKM, dan meningkatkan minat kunjungan wisata halal di Indonesia. Namun, nampaknya sejauh ini perkembangan Pariwisata Indonesia masih belum siap untuk melakukan akselerasi di Sektor Pariwisata khususnya penggunaan E-marketing berbasis Fintech Syariah.
\end{abstract}

Kata kunci: Manajemen Strategi, Fintech, Lingkungan eksternal dan Internal Organisasi, Wisata Halal.

Fauzi. 2020. Model e-Marketing berbasis Fintech Syariah Berdasarkan Tinjauan Lingkungan Eksternal dan Internal untuk Pengembangan Wisata Halal Di Indonesia. Jurnal Syarikah 6(1): 58-66.

\section{PENDAHULUAN}

Setelah 5 tahun kembangkan 'halal tourism', Indonesia akhirnya menduduki peringkat pertama wisata halal dunia pada tahun 2019. Prestasi di tahun 2020 tersebut mendorong pemerintah kembali merancang empat destinasi pariwisata super prioritas 
yakni danau Toba, Borobudur, Labuan Bajo, dan Mandalika. Proyek besar ini akan melibatkan berbagai kementerian dan Badan Pariwisata dan Ekonomi Kreatif (Bekraf). Disisi lain, kendala turunnya devisa pariwisata dan kinerja indusri pariwisata akan mendatangkan masalah. Hampir separuh neraca jasa pada current account Indonesia disumbangkan oleh jasa perjalanan, namun devisa yang masuk dari jasa pariwisata sepanjang semester I-2019 hanya berjumlah sebesar US\$ 6,42 miliar atau tumbuh sebesar 0,09\% yoy jauh lebih kecil dibandingkan tahun sebelumnya sebesar 7,38\%. Sejauh ini, terjadinya perlambatan pertumbuhan kunjungan wisata mancanegara ke Indonesia (CNBC, 2019).

Indonesia mulai menempatkan sektor pariwisata sebagai salah satu target pendapatan nasional (APBN). Walaupun tidak signifikan, namun ini menunjukkan bahwa wilayah Indonesia memiliki keunggulan dari segi industri pariwisata. Berdasarkan data Badan Pusat statistik,(BPS, 2019) "jumlah kunjungan wisata ke Indonesia sejak tahun 2014 hingga 2018 mengalami peningkatan sebesar $14 \%$ pertahun hingga tahun 2018 kunjungan wisatawan mancanegara ke Indonesia mencapai 15,81 juta orang atau tumbuh 2,5 kali lipat dibandingkan pada tahun 2009 dan sampai bulan April menurun sebesar 2,74\%. E-Marketing berbasis Fintech Syariah diharapkan dapat mendukung perkembangan Sektor wisata halal dan UMKM kedepannya.

Perkembangan teknologi digital yang terus meningkat mendorong Kementerian pariwisata mengeluarkan strategi baru dengan menawarkan 100 destinasi digital dan nomadic tourism untuk merealisasikan kunjungan target wisata mancanegara (Maritim, 2019). Kehadiran e-marketing berbasis Financial Technology dapat membawa nuansa baru bagi sektor Pariwisata di Indonesia. Di tengah berbagai kendala kinerja pariwisata, E-Marketing dapat memperkuat daya tarik kunjungan wisata mancanegara dan Fintech hadir memberikan kemudahan transaksi keuangan dengan mempunyai jangkauan sangat luas dan lebih efisien. Selain itu, Fintech dapat tumbuh bermanfaat bagi pelaku UMKM yang dapat ikut diperdayakan melalui sektor pariwisata. Tak mau ketinggalan Fintech syariah mulai tumbuh memberikan solusi pendanaan dan trasaksi keuangan bagi masyarakat khususnya umat muslim. Semacam suatu keharusan untuk melakukan aktivitas ekonomi berdasarkan prinsip-prinsip dan nilai-nilai yang harus sesuai dengan hukum syariah.

'Halal Tourism' harus memiliki keunggulan dan kemampuan bersaing bila ingin berhasil merancang dan mengimplementasikan strategi kompetitif dan bertahan dalam situasi perekonomian seperti saat ini. Keunggulan 'Halal Tourism' dapat dilakukan dengan menyusun strategi berdasarkan analisis lingkungan eksternal dan internal organisasi. Pemerintah dapat menempatkan diri dalam posisi bertahan dan melakukan akselerasi serta inovasi baru dalam produk dan jasa.

\section{MATERI DAN METODE}

\section{Tujuan Analisis Lingkungan Organisasi}

Kelangsungan hidup organisasi sangat tergantung pada respon dan adaptasi organisasi sebagai konsekuensinya. Pada dasarnya lingkungan bisnis menggabungkan tiga dimensi yaitu; 1) turbulensi lingkungan (environmental turbulance) sebagai tingkat inovasi industri ditengah ketidakpastian kompetensi dan arah pasar (Kipley et al, 2012); 2) persaingan pasar (environmental hostility) yang ditentukan oleh tingkat ancaman sebagai hasil dari kompetensi yang kompleks, intens, dan stabil (Zahra et al, 2000); 3) heterogenitas Lingkungan (environmental heterogeneity) sebagai keragaman pasar dan variasi yang dihasilkan dibidang manufaktur dan pemasaran strategi yang dikembangkan (Porter, 1980).

Inovasi mempunyai peranan pada produk dan layanan pengembangan UKM 
dengan taktik 'order winner' (Beaver \& Pangeran, 2002). David (2010), "lingkungan eksternal perusahaan merupakan faktorfaktor yang berada diluar perusahaan pada saat membuat keputusan yang mempunyai potensi untuk mempengaruhi struktur organisasi perusahaan". Sedangkan lingkungan internal adalah proses perencanaan strategi yang mengkaji bidang pemasaran dan distribusi dalam rangka mengembangkan sumber daya yang ada dan faktor-faktor keuangan serta akuntansi untuk menganalisis kekuatan dan kelemahan dari masing-masing divisi sehingga perusahaan dapat melakkan tindakan pengambilan keputusan dengan memanfaatkan peluang yang ada secara efektif dan efisien dari ancaman dan hambatan (Lawrence \& William, 1998).

Menurut Wheelen dan Hunger (2002) Lingkungan eksternal memiliki dua bagian yaitu 1) lingkungan kerja yang secara langsung dipengaruhi operasional organisasi dengan beberapa elemen diantaranya pemerintah, pemasok, dan komunitas lokal; dan 2) lingkungan sosial yang mempengaruhi keputusan jangka panjang dan dipnegaruhi oleh elemenelemmen yang terdiri dari kekuatan ekonomi (pertukaran materil, uang, energi dan informasi), kekuatan tekonologi, kekuatan hukum dan kekuatan sosial kultur. Komponen analisis lingkungan eksternal terdiri dari empat tahap yaitu; 1) pemindaian (scanning) untuk mengindikasi tanda-tanda awal perubahan potensial lingkungan; 2) pengawasan (monitoring) untuk mengamati suatu tren yang ada dimasyarakat; 3) peramalan (forecasting) yang digunakan untuk mengembangkan proyek-proyek yang layak tentang apa yang mungkin terjadi dan seberapa cepat perubahan-perubahan dan trend tersebut dideteksi melalui pemindaian dan pengawasan; dan 4) penilaian (assesing) untuk menentukan waktu dan siginfikasi efek dari perubahan dan tren lingkungan terhadap manajemen strategi perusahaan (Hitt, Duane, \& Hoskison, 2001). Lebih lanjut lagi, disebutkan analisis untuk menentukan faktor-faktor eksternal lingkungan perusahaan dapat menggunakan Alat analisis Faktor Strategik Eksternal (EFAS) yang bertujuan untuk mengukur seberapa baik manajemen (rating) menanggapi faktor-faktor tertentu dalam hal tingkat pentingnya (bobot) tersebut bagi perusahaan dnegan mengindikasi peluang dan ancaman dari luar perusahaan. Adapun alat analisis yang digunakan untuk mengindikasi lingkungan perusahaan diantara adalah sebagaimana berikut ini.

\section{Analisis Struktur Industri}

Salah satu analisis ekonomi industri adalah hubungan antara struktur perilaku kinerja atau Structure Conduct Performamnce (SCP) dimana terdapat hubungan paling sederhana dimana struktur mempengaruhi perilaku kemudian perilaku mempengaruhi kinerja organisasi perusahaan. Dalam SCP, hubungan ketiganya saling mempengaruhi satu sama lain termasuk karena adanya perkembangan teknologi (Martin, 1994).

\section{Analisis Lima Kekuatan (Five Force)}

Analisis lima kekuatan seringkali digunakan untuk mencari tahu kebutuhan pelanggan secara bersama terhubung ke pengadaaan bahan baku komponen, pembuatan atau perakitan produk, logistik, pengiriman produk dan layanan dukungan untuk mencapa pangsa pasar dan laba yag lebih tinggi. Analisis Porter's Five Force' yang terdiri dari persaingan kompetitif, kekuatan pemasok, kekuatan pembeli, ancaman substitusi dan ancaman potensial baru sangat cocok untuk membuat sebuah kesimpulan dari dampak negatif dan positif dari manjemen pasokan berbasis teknologi atau yang lebih dikenal dengan E-SCM (Barutçu and Tunca, 2012). Model analisis ini sederhana namun sangat kuat untuk menentukan tingkat persaingan dalam suatu industri. Dalam Istilah five force, daya tarik industri berhasil memperbaiki posisi perusahaan dan menyusun kembali strategi untuk mendapatkan keunggulan kompetitif. Dengan menggabungkan lima kekuatan dapat menetukan potensi keuntungan 
utama suatu industri. Apabila dari masingmasing kekuatan tinggi, perusahaan tidak menentukan harga produk dengan mudah dan memperoleh keuntungan yang besarn (Thomson et al, 1995). Sebagaimana pada gambar berikut ini;

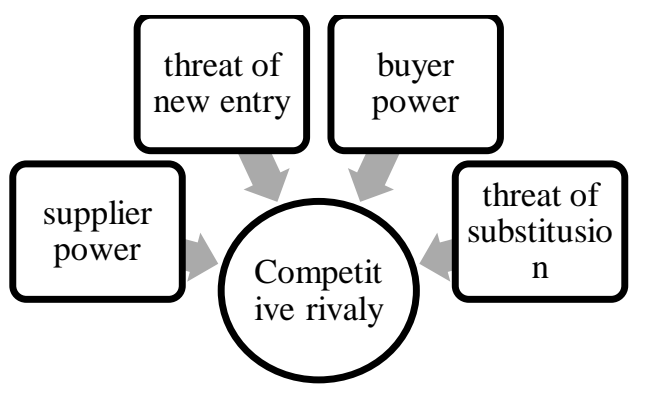

Sumber: Porter, 1980

\section{Gambar 1. The Five Force Strategic Analysis}

Gambar 1 membahas kekuatan yang terdapat dalam analisis five force. Jika pemasok dapat mengubah harga dengan mudah, mereka memiliki kekuatan pemasok. Pemasok memiliki persaingan dalam industri melalui penawaran daya tawar mereka. Jika perusahaan sulit untuk masuk ke industri baru, kompetitif akan masuk. Beberapa hambatan masuk yang umum terjadi adalah adanya hubungan jangka panjang dengan pelanggan, persyaratan modal, skala ekonomi, pengalihan perbedaan harga, dan kebijakan pemerintah. Apabila disetujui barulah tingkat pertumbuhan industri dan hambatan masuk tinggi menguntungkan perusahaan.

\section{Analisis STEEPLE}

Analisis Steeple atau lebih dikenal dengan PEST Analysis yang terdiri dari Politik, ekonomi, sosial dan teknologi yaitu sebuah alat analisis untuk peremncanaan strategis yang digunakan dalam mengevaluasi dampak dari faktor-faktor tersebut terhadap suatu proyek tertentu (More, Probert, \& Phaal, 2015). Adapun 4 empat analisis steeple yaitu; 1) faktor politik yang digunakan untuk menilai bagaimana peraturan pemerintah dan faktor hukum dalam mempengaruhi lingkungan bisnis dan perdagangan misalnya stabilitas politik, ideologi negara dan regulasi ketenagakerjaan; 2) faktor ekonomi mencakup faktor-faktor seperti inflasi dan pertumbuhan ekonomi pada negara yang bersangkutan; 3) faktor sosial umumnya meninjau elemen-elemen seperti demografi pelanggan, sosial budaya, serta sikap dan gaya hidup; dan 4) faktor teknologi yang digunakan untuk mengetahui bagaimana dampak teknologi terhadap pengenalan produk atau layanan ke pasar termasuk dalam hal kemajuan teknologi, siklus, dan peran pemerintah (Aguilar, 1967).

\section{Analisis Nilai}

Porter (1990) mengembangkan alat analisis internal yang disebut analisis nilai (value chain) yang merupakan teknik untuk memandang secara sistematik organisasi dalam melayani pelanggan. Rantai nilai mengkategorikan aktivitas secara umum tentang nilai tambh dari sebuah organisasi melipui logistik masuk dan keluar, produksi, pengadaan, pemasaran, infrastruktur dan sumber daya. Tipe aktivitas organisasi terdiri dari 3 (tiga) macam yaitu 1) aktivitas langsung yang terlibat dalam menciptakan nilai kepada pelanggan, tidak langsung; 2) tidak langsung untuk memungkinkan aktivitas secara langsung secara terus menerus; dan 3) jaminan kualitas yang menjamin pemantauan, inspeksi, penyesuaian, dan administrasi. Metode ini meliputi 1) identifikasi analisis value chain industri, pembebanan cost, pendapatan dan aset untuk nilai aktivitas organisasi secara internal; dan 2) mendiagnosis cost driver yang berhubungan dengan volume input, cost (variabel, rata-rata, marginal, profit), analisis break event, budget fleksibel, dan margin kontribusi. Belajar dari analisis rantai nilai, masalah bukan pada apakah berpartisipasi dalam lingkungan organisasi tetapi bagaimana melakukannya dengan metode yang tepat untuk perkembangan masa depan organisasi yang lebih baik (Kaplinsky, 2000).

\section{Analisis Sumber Daya Organisasi}

Teori berdasarkan sumber daya dari organisasi secara luas mengakui bahwa 
kemampuan yang unik dan penting untuk mencapai keunggulan kompetitif yang berkelanjutan (Coates \& McDermott, 2002). Analisis sumber daya organisasi (resource based view $R B V$ ) merupakan metode untuk menganalisis dan mengindentifikasi keunggulan strategi suatu perusahaan yang didasarkan pada tinjauan terhadap suatu kombinasi dari aset keahlian yang dimiliki, kapabilitas, dan aset tak berwujud yang spesial. Asumsi yang umum digunakan adalah bahwa perusahaan berbeda secara fundamental karena setiap organisasi mempunyai; kumpulan; sumber daya (berwujud dan tidak berwujud) yang khas berupa aset serta kapabilitas organisasi untuk memanfaatkannya. Ada beberapa kriteria yang diusulkan dalam metode ini, 1) penting untuk dapat memenuhi suatu kebutuhsan pelanggan secara baik dibandingkan dengan substitusi lain; 2) langka apabila hanya sedikit pihak yang mempunyai sumber daya atau suatu keahlian tertentu setingkat yang dimiliki organisasi tersebut yang terdiri dari empat karakteritik dengan mekanisme isolasi yaitu sumber daya unik secara fisik, sumber daya yang dikembangkan unik atau sulit ditiru, ambiguitas, dan hambatan ekonomi untuk mempersulit imitasi; 3) menghasilkan bagian terbesar dari laba keseluruhan dengan cara membentuk patungan dari perusahaan atau organisasi lain; dan 4) mempunyai sifat tahan lama atau berkesinambungan.(Porter, 1990)

\section{Metode Penelitian}

Penelitian menggunakan pendekatan deskriptif kualitatif artinya bahwa penelitian dilakukan dengan mengumpulkan data dna informasi tentang keadaaan dan fenomena yang saat ini sementara berlangsung (Sugiyono, 2014). Pendekatan dilakukan untuk melakukan analisis lingkungan internal dan eksternal di sektor wisata halal dengan tujuan untuk memprediksi sejauh mana kemungkinan pengembangan UMKM melalui sektor ini dengan memanfaatkan Fintech syariah sebagai akses pendanaan dan transaksi ekonomi lainnya selain lembaga keuangan lainnya. Data-data pustaka dan informasi terkait digunakan untuk menganalisis dan membandingkan kenyataan yang sedang berlangsung dengan penggunaan teori yang disajikan peneliti dengan memfokuskan pada deskripsi dan analisis faktor-faktor internal dan eksternal dan penerapan strateig yang dapat dilakukan. Teknik pengumpulan data dilakukan melalui studi pustaka yang diperoleh dari penelitianterdahulu dan data statistik pariwisata Indonesia dan dokumen lainnya yang terkait dengan penelitian.

\section{HASIL DAN PEMBAHASAN}

Menurut Armstrong dan Kotler (2008), "E-marketing seringkali digunakan untuk mengkomunikasikan atau memberi tahu sesuatu, mempromosikannya dan menjualnya suatu barang/ jasa melalui internet. Dalam bidang pariwisata, emarketing telah diimplementasikan dalam mempromosikan 'wonderful Indonesia' dimata dunia. Walaupun tidak secara gencar, namun nyatanya promosi melalui emarketing dibutuhkan dalam era digitalisasi seperti saat ini. Dengan basis Fintech dalam mempercepat pengembangan industri prioritas seperti pariwisata dan UMKM tentunya strategi dalam menarik minat wisatawan diharapkan akan semakin meningkat, efektif dan efisien karena saat ini masyarakat sadar akan penggunaan teknologi dalam segala aktivitas kehidupannya (Alaeddin \& Altounjy, 2018);(Hamdan \& Hoon, 2019). Sebuah model konsep pengembangan pariwisata dalam model e-marketing berbasis fintech sebagaimana berikut ini; 


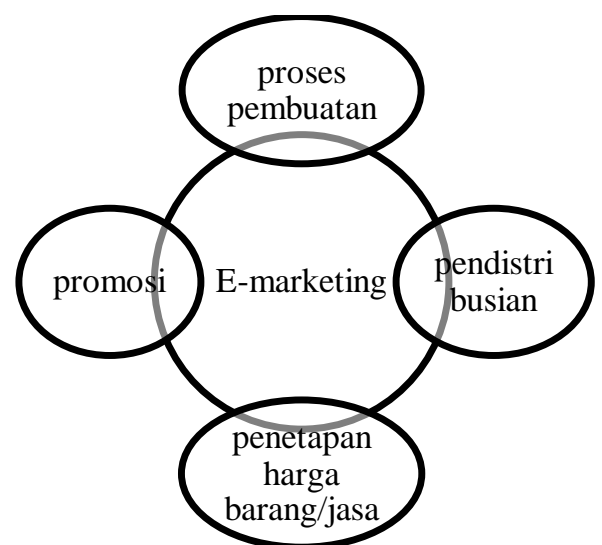

Sumber: Strauss \& Frost,2011; Boone \& Kurtz,2007

\section{Gambar 2. Strategy e-Marketing}

Empat strategi marketing yang digunakan e-marketing kemudian dikolaborasikan dengan fintech. Promosi juga menginformasikan kemudahan transaksi 'halal tourism'. Selama ini, industri wisata halal lebih memprioritaskan dalam hal meningkatkan performa dalam bentuk fisik dari destinasi wisata seperti fasilitas dan sarana prasarana dari produk, satu yang kadang terlupakan dalam layanan jasa bahwa wisman juga membutuhkan akses transaksi yang aman dan efesien seperti halnya fintech syariah. Oleh karena itu, proses e-marketing berbasis fintech juga harus diperhatikan, bagaimana teknik pendistribusiannya dan soal penetapan jasa yang akan dilakukan tentunya ini merupakan sebuah catatan penting sebelum melakukan strategi e-marketing berbasis fintech syariah. Fintech syariah sangat cocok dengan wisata halal karena keduanya merupakan produk syariah dimana didalamnya terkandung ciri khas yang menjadi pembeda dari pesaingnya yaitu konvensional. Produk syariah mengendepankan nilai-nilai Islami, speeti larangna riba, gharar dan maysir, etika bisnis yang baik dan benar, mengedapankan konsep kemaslahatan dan keadilan serta tata kelola organisasi yang baik (Sharia Corporate Govenrnance)

Bagi pelaku UMKM, fintech syariah merupakan salah satu solusi untuk mengatasi keterbatasan modal yang dibutuhkan dalam mengembangkan daya tarik destinasi wisata di daerahnya. Fintech syariah memberikan akses kesegala arah sesuai dengan kebutuhan masyarakat, tinggal bagaimana masyarakat dapat bernovasi dan mengembangkannya. Sebagai langkah awal, pemindaian lingkungan eksternal dan internal harus dilakukan. Berbagai analisis dapat dilakukan untuk membentuk sebuah model strategis penggunaan $e$-marketing berbasis fintech. Akses dan jangkauan yang luas dapat meliputi wilayah Indonesia yang berkepulauan. Namun, semua itu membutuhkan data yang konkrit, sumber keuangan dan jaringan internet yang kuat yang hanya dapat dilakukan dengan melakukan analisis terhadap lokasi dan lingkungan dimana destinasi wisata halal akan dikembangkan.

Terdiri dari lima komponen analisis lingkungan yang dapat dilakukan dan secara keseluruhan dapat dibuat dalam bentuk tabel sebagaimana berikut ini;

Tabel 1 Komponen Analisis Lingkungan

Eksternal dan Internal Pada Sektor Pariwisata Halal dan UMKM

\begin{tabular}{lll}
\hline Kualifikasi & \multicolumn{1}{c}{ Alat } & Konsep strategi \\
& Analisis & \\
\hline Lingkunga & Analisis & Menganalisis \\
Eksternal & Struktur & perilaku \\
& Industri & wisatawan \\
& & mancanegara \\
& & yang dapat \\
& & mempengaruhi \\
& & wisata halal \\
& & misalnya pola \\
& & konsumsi dan \\
& penggunaan \\
& & fintech dalam \\
& & transaksi \\
& & keuangan \\
& & (pemesan tiket \\
& & tour and travel \\
& & online) \\
\hline & Analisis & Mencari tahu apa \\
& Five & yang dibutuhan \\
& Force & wisman dengan \\
& menganalisis \\
& pesaing (wisata \\
\hline
\end{tabular}




\begin{tabular}{|c|c|}
\hline & $\begin{array}{l}\text { negara lain dan } \\
\text { fintech } \\
\text { konvensional), } \\
\text { kekuatan } \\
\text { pengunjung } \\
\text { dalam membeli } \\
\text { produk/jasa } \\
\text { wisata, adanya } \\
\text { barang substitusi } \\
\text { (produk/jasa } \\
\text { yang lebih murah } \\
\text { dengan kualitas } \\
\text { yang sama dari } \\
\text { negara pesaing), } \\
\text { sejauhmana } \\
\text { kekuatan } \\
\text { pemasok dalam } \\
\text { hal ini berkenaan } \\
\text { dengan barang } \\
\text { impor yang } \\
\text { dibutuhkan } \\
\text { untuk pengembangan } \\
\text { wisata halal dan } \\
\text { pelaku UMKM, } \\
\text { dan dukungan } \\
\text { kuat yang harus } \\
\text { diberikan } \\
\text { pemerintah } \\
\text { terutama } \\
\text { regulasi } \\
\text { perlindungan } \\
\text { konsumen }\end{array}$ \\
\hline $\begin{array}{l}\text { Analisis } \\
\text { STEEPL } \\
\text { E }\end{array}$ & $\begin{array}{lr}\text { Situasi politik } \\
\text { yang aman } \\
\text { dibutuhkan, } \\
\text { sosial-ekonomi } \\
\text { harus tetap } \\
\text { stabil, dan } \\
\text { teknologi } \\
\text { marketing } \\
\text { berbasis fintech } \\
\text { menjadi salah } \\
\text { satu } \\
\text { perencanaan } \\
\text { program } \\
\text { percepatan } \\
\text { wisata halal } \\
\text { modern }\end{array}$ \\
\hline
\end{tabular}

\begin{tabular}{|c|c|c|}
\hline $\begin{array}{l}\text { Lingkunga } \\
\text { n Internal }\end{array}$ & $\begin{array}{l}\text { Analisis } \\
\text { Rantai } \\
\text { Nilai }\end{array}$ & $\begin{array}{l}\text { Keterlibatan } \\
\text { seluruh } \\
\text { pemangku } \\
\text { kepentingan } \\
\text { termasuk pelaku } \\
\text { UMKM, } \\
\text { pemerintah dan } \\
\text { pihak swasta } \\
\text { untuk } \\
\text { menciptakan } \\
\text { nilai tambah dari } \\
\text { wisata halal. } \\
\text { Salah satunya } \\
\text { saja tidak turut } \\
\text { berkontribusi } \\
\text { akan terjadi } \\
\text { ketidak seimbangan yang } \\
\text { dapat menjadi } \\
\text { cikal bakal } \\
\text { hambatan dan } \\
\text { kendala internal }\end{array}$ \\
\hline & $\begin{array}{l}\text { Analisis } \\
\text { Sumber } \\
\text { Daya }\end{array}$ & 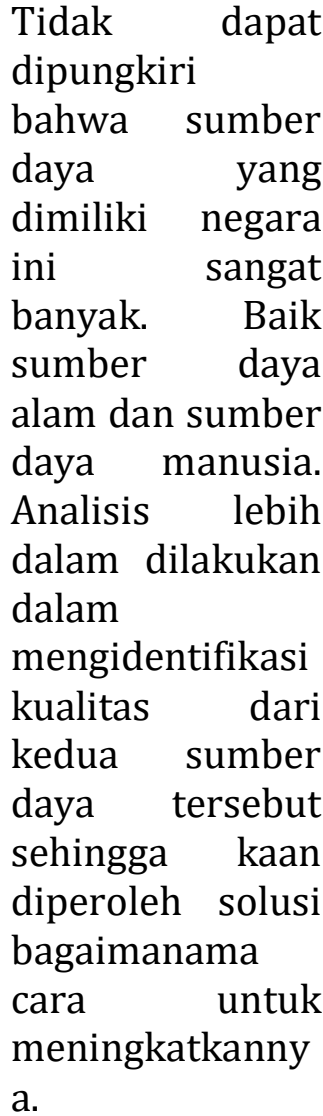 \\
\hline
\end{tabular}

Tabel 1 merupakan gambaran umum yang dapat dilakukan untuk membuat semacam model strategis e-marketing berbasis fintech pada zona wisata halal di 
Indonesia dengan asumsi bahwa analisis lingkugan eksternal dan internal adalah dalam keadaan normal. Mengidentifikasi lingkungan destinasi wisata untuk menciptakan peluang meningkatkan APBN dan kesejahteraan. Masyarakat melalui destinasi wisata halal membutuhkan bukan hanya modal tetapi juga sumber daya manusia yang berkualitas dan salah satu upaya yang dapat dilakukan adalah dengan mengembangkan produk-produk syariah yang sudah terbukti keunggulannya. Berdasarkan penjelasan yang dikemukakan diatas, dapat diperoleh bentuk desain model e-marketing berbasis fintech syariah berdasarkan lingkungan eksternal dan internal wisata halal dapat digambarkan dalam skema berikut ini;

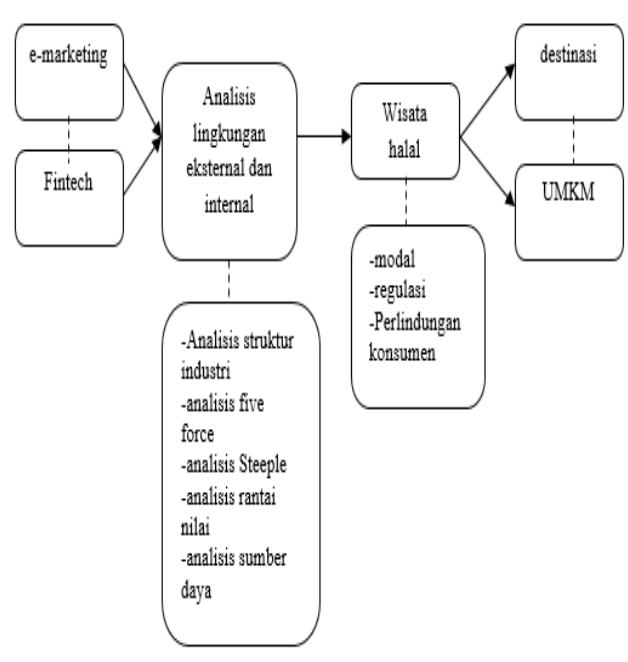

Gambar 3. Model e-marketing berbasis fintech Wisata Halal

\section{KESIMPULAN DAN IMPLIKASI}

E-Marketing berbasis fintech dapat membuka peluang potensi strategis dalam meningkatkan minat Wisman untuk berkunjung ke Indonesia. Kemajuan teknologi membuat jalan kedepan akan prospek ini semakin baik. Analisis terhadap lingkungan eksternal dan internal baik dari wilayah 'halal tourism' dan UMKM dapat membantu dalam merumuskan stratgi yang menunjang keberhasilan daalm meningkatkan kesejahteraan masyarakat melalui bidang pariwisata. Dan semua itu membutuhkan dukungan dari stake holder. E-Marketing berbasis finetch akan mengalami kendala yang cukup berat apabila sumber daya manusia yang dibutuhkan dan dana yang diharapkan dalam mendukung program tidak sejalan dengan kemampuan pemerintah untuk mengakomodir indikator tersebut.

\section{DAFTAR PUSTAKA}

Alaeddin, O. \& Altounjy, Rana. 2018. Trust, Technology Awarenenss and Satisfaction Effect into the Intention to Use Cryptocurrency among Generation $\mathrm{Z}$ in Malaysia. International Journal of Engineering \& Technology 7(4.29): pp.8-10.

Aguilar, F.J. 1967. Scanning the business environmet. Macmillan.

BPS (Badan Pusat Statistik). 2019. Data Statistik Sektor Pariwisata. bps.go.id. URL:https://www.bps.go.id/subject/16/ pariwisata.html

Barutcu, S. \& Tunca, M.Z. 2012. The Impact of E-SCM on the E-Tailing Industry: An Analysis from Porter's Five Force Perspectives. Procedia- Social and Behavioral Sciences 58(12): pp. 10471056.

Biro Perencanaan dan Informasi. 2019. Tawarkan 100 Destinasi Digital dan Nomadic Tourism Strategi Baru Menpar Datangkan 17 juta Wisman dan 275 Juta Wisnus di Tahun 2018. maritim.go.id. URL:https://maritim.go.id/destinasidigital-dan-nomadic-tourism/

Boone \& Kurtz. 2007. Pengantar Bisnis Kontemporer. Edisi 11. Jakarta: Salemba Empat.

CNBC Indonesia. 2019. Membedah Destinasi Wisata Super Prioritas Jokowi di 2020. Cnbcindonesia.com.URL:

https://www.cnbcindonesia.com/news/2 0190817214027-4-92773/membedahdestinasi-wisata-super-prioritas-jokowi$\underline{\mathrm{di}-2020}$

Coates, Theresa T. \& McDermott C.M. 2002. An exploratory analysis of new 
competencies: a resource based view perspective. Journal of Operations Management 20 (5): pp. 435-450. https://doi.org/10.1016/S02726963(02)00023-2

David, Fred. 2010. Konsep Manajemen. Jakarta: PT. Prenhallindo.

Davies, B.M. \& Thomson, D.J. 1995. The Atmospheric Dispersion modelling System (ADMS): comparisons with data from the Kincaid experiment. Int. J. Environment and Pollution, 5(4-6):pp. 383-400.

Hamdan, M \& Hoo, Chang-Yau. 2019. Brunei Darusslam: Making Strides with a Renewed Focus on The Future. Southeast Asian Affairs. pp. 84-102.

Hitt, M.A., Ireland, R.D. \& Hoskisson, R.E. 2001. Strategic Management: Competitiveness and Globalization, Edisi Bahasa Indonesia. Jakarta: Salemba Empat.

Jauch, Lawrence R. \& Willian F. Glueck. 1998. Manajemen Strategis dan Kebijakan Perusahaan. Edisi Ketiga. Jakarta: Erlangga.

Kaplinsky, R. 2000. Globalisation and Unequalisation: What Can Be Learned from Value Chain Analysis. The Journal of Development Studies, 37(2): pp. 117146.

Kipley, Dan., Lewis, A., \& Jewe, R. 2012. Entropy-distrupting Ansoff's five levels of envoronmentsl turbulance. Business Strategy Series, 13(6): pp. 251262.https://doi.org/10.1108/1751563121 1286083

Kotler \& Amastrong, S. 2008.Prinsip-Prinsip Pemasaran. Jakarta: Erlangga

Porter, M. 1980. Competitive Strategy, Techniques for Analyzing Industries and Competitiors. New York: The Free Press.

Porter, M.E. 1980. Competitive Strategy. Tecneques for Analysing Industries and Competitors. New York: The Free Press.
Martin, S. 1994. Industrial Economic: Economic Analysis and Public Policy Second Edition. New Jersey: PrenticeHall.

More, E., Probert, D., \& Phaal, R. 2015. Improving long-term strategic planning: An analysis of STEEPLE factors identified in environmental scanning brainstorms. Proceeding of PICMET '15: Management of the Tecnology Age. Pp.

381-394.DOI: 10.1109/PICMET.2015.7273126

Strauss, J. \& Frost, R. 2011. E-Marketing edist International ke 6. London: Pearson.

Sugiyono. 2014. Metde Penelitan Kuantitatif, Kualitaif, dan R\&D. Bandung: Alfabeta.

Wheelen \& Hunger. 2002. Strategic Management And Business Policy. New Jersey: Pearson Prentice Hall.

Zahra, Shaker A. \& Garvis, Dennis M. 2000. Internasional corporate entrepreneurship and firm performance: The moderating effect of international environmental hostiliy. Journal of Business Venturing 15(5-6): $\quad$ pp. 469-492. https://doi.org/10.1016/S08839026(99)00036-1 